\title{
Influence of Mint and Peppermint on Tetranychus urticae and Some Predacious Mites of the Family Phytoseiidae (Acari: Tetranychidae: Phytoseiidae)
}

\author{
F. M. MOMEN ${ }^{1}$, S. A. A. AMER ${ }^{1}$ and A. M. REFAAT ${ }^{2}$ \\ ${ }^{1}$ Department of Plant Protection, \\ ${ }^{2}$ Department of Cultivation and Production of the Medicinal and Aromatic Plants, \\ National Research Centre, Dokki, Cairo, Egypt
}

\begin{abstract}
The deterrent and toxicity effects of mint, Mentha virdis L. and peppermint, Mentha piperita L. on Tetranychus urticae Koch were studied under laboratory conditions. M. virdis was more potent for T. urticae than $M$. piperita, with a significant increase in repellency. Leaf discs treated with increasing concentrations of both materials showed reduction in the total numbers of eggs laid. A high percentage of T. urticae mortality was recorded in case of M. virdis. The direct toxicity of both essential oils to the female of the predacious mites namely Typhlodromus athiase Porath and Swirski Phytoseius finitimus Ribaga, Amblyseius barkeri (Hughes), Amblyseius zaheri Yousef and El-Borolossy, Amblyseius yousefi Zaher and El-Borolossy and Amblyseius deleoni (Muma and Denmark) were tested. $\mathrm{At}_{\mathrm{LC}_{50}}$ level, M. virdis was the most toxic to females A. yousefi and the least to females T. athiasae. With the exception of A. zaheri, M. piperita proved to be more toxic to the predacious mites tested than M. virdis. The results obtained chemically and biologically, may suggest that the higher percentage of the hydrocarbons of $M$. virdis were responsible for the toxic effect.
\end{abstract}

Keywords: Mentha piperita, Mentha virdis, Phytoseiidae Predacious mites, Tetranychus urticae.

Aromatic plants have traditionally been used in folk medicine. Recently, the interest of the biological activities of extracts has been the subject of intense scientific investigation. Essential oils drived from many plants are known to possess biological activity against prokaryotic (Deans and Ritchie, 1987) and eukaryotic organisms (Konstantopoulou et al., 1992). The existence of different chemotypes, based on qualitative differences within a taxon, is a common feature in most Mentha species and hybrids (Kokkini, 1991). Summarizing research published to date, it can be concluded that the main monoterpenes which characterize the essential oil composition of the different species and hybrids are either cyclic C-2 (such as carvone, hydrocarvone) or C-3 (such as menthone, pulegone) substituted compounds (Kokkini, 1992).

Recently, mites infesting food products became a dangerous problem, also the rise of resistance among its population implied the necessity need to look for combinations of acaricides of different modes of action as alternative methods of mite control, to face the serious problems created by using acaricides. The utilization of some plants against the mite attack, have prompted us to initiate a program for using plant extracts for the biological activity. Among these botanicals, the essential oils which exhibit antifeedant activity and toxic to some important insects (Su et al., 1972; Don-Pedro, 1985; Tare and Sharma, 1988). The effect of the essential oils on pest mites has been studied by Amer et al. (1993); Ibrahim et al. (1993); Perrucci (1995); El-Gengaihi et al. 
(1996); Amer et al. (in prep.). The role of phytoseiid mites as predators of phytophagous mites and insects on various kinds of crops is well documented (Huffaker et al., 1970). However, the phytoseiid predators, A. barkeri, A. zaheri, T. athiasae, A. deleoni, A. yousefi and $P$. finitimus have been evaluated for control of spider mites on crops and orchards with promising results (Swirski et al., 1967; El-Banhawy, 1974; Momen, 1995; Abou-Elella, 1998; Momen and El-Borolossy, 1999). Therefore, in the presence of essential oil applications, biological control of spider mites may be achieved by the selective use of essential oil that are less toxic to natural enemies than to pest species. The present work was carried out to complete previous work discussed the activity of some essential oils on the pest T. urticae which is very harmful to agriculture. Knowledge of the effects of both materials tested on natural enemies of phytophagous mites and insects is also provided.

\section{Materials and Methods}

\section{Plant materials}

The essential oil of mint and peppermint plants was obtained during the last week of June 1997 from plants grown in the Experimental farm of National Research Centre at Giza.

\section{Preparation of the oil}

The air-dried plant material (aerial parts) was pulverized and the essential oils isolated after hydrodistillation for 3 hours using Clevenger apparatus. The freshly distilled oil of each plant was dehydrated over anhydrus sodium sulphate and then subjected to GCMS analysis under the following conditions: Apparatus: Varion 3400 gas chromatograph with mass selective detector operated in electron ionization mode at $70 \mathrm{ev}$. The column used for oil separation was a fused silica DB-5 column, $30 \mathrm{~m} \times 0.25 \mathrm{~mm}$ i-d., film thickness 0.25 .

Chromatographic investigation of the volatile oil. Mass spectra were obtained by a Hewlett-Packard 5890 gas chromatograph coupled with mass detector. Carrier gas: helium at $1 \mathrm{ml} / \mathrm{min}$., temp. programming $60-200{ }^{\circ} \mathrm{C}$ at rate of $3{ }^{\circ} \mathrm{C} / \mathrm{min}$.; chart speed: 0.6 $\mathrm{cm} / \mathrm{min}$., injection part temp.: $150^{\circ} \mathrm{C}$; split ratio 100:1; start stop masses 39-250; electron multiplier voltage $1800 \mathrm{ev}$. Identification of the constituents was performed by comparison of their retention times and mass spectral fragmentations with those of the published data by Adams (1989). Quantitative determination was carried out based on peak area measurements.

\section{Preparation of the emulsions}

Emulsions of mint (Mentha virdis) and peppermint (Mentha piperita) were prepared by mixing of Triton-x 100. Different concentrations of the product were prepared and tested against the adult females of mites. 


\section{Maintenance of mite stock cultures}

The stock cultures of T. urticae were collected from infested lima bean (Phaseolus vulgaris L.) in the laboratory at N. R. C. Cairo. The following predacious mites were used in our studies, $A$. zaheri and A. barkeri were found on leaves of eggplants; P. finitimus was collected from fig oechards; A. deleoni and T. athiasae were found on mango leaves; $A$. yousefi was found on leaves of Zizyptus spina-christi, L. All these strains have been maintained in the laboratory for 3 years. All strains were kept separately on detached bean leaves $P$. vulgaris placed on wet cotton wool with $T$. urticae as prey.

\section{Treatment}

\section{REPELLENCY AND TOXICITY TEST PROCEDURE FOR ADULT FEMALES OF T. URTICAE}

Raspberry leaf discs ( $3 \mathrm{~cm}$ in dia.) were placed with the lower surface upwards in a petri-dish lined with moist cotton wool. One half of each disc was treated separately with selected concentrations of both oils, while the other served as a control. Ten adult females of T. urticae were then introduced into the middle of each leaf disc. Ten replicates leaf discs were used per concentration. Orientation of the females T. urticae on treated and control discs recorded after 24, 48 and $72 \mathrm{~h}$ after treatment. The number of eggs laid on both sides and the percentage mortality of adult females were recorded after $72 \mathrm{~h}$. The repellency was calculated according to Lwand et al. (1985).

\section{TOXICITY AND BIOLOGICAL EFFECTS OF MINT AND PEPPERMINT ON ADULT FEMALES OF}

\section{T. URTICAE}

Newly emerged females $T$. urticae were transferred singly on raspberry leaf discs treated with different concentrations of mint and peppermint. The total number of eggs laid were recorded over a period of 10 days. The mortality of the females was also recorded. Each concentration was replicated 20 times and a similar number of discs treated with water only as a control. The different indices were calculated as reported by Lundgren (1975).

\section{DIRECT EFFECT ON SOME PREDACIOUS MITES}

Adult females of 6 predators species (A. barkeri, A. deleoni, A. zaheri, A. yousefi, $T$. athiasae and $P$. finitimus) were sprayed with different concentrations from both materials using glass atomizer. Females were confined on the lower surfaces of detached raspberry clean leaves $(5 \mathrm{~cm}$ in dia.) while the upper surfaces were placed on cotton saturated with water. Each test contained 5 concentrations and each concentration had 4 replicates (20 females/replicate). In every test, a control was included. Mortality was recorded $48 \mathrm{~h}$ after application. Corrected mortality counts according to Abbott's formula (1925) and were statistically analysed by Finney (1952).

All the experiments reported herein were carried out the laboratory at $27 \pm 2{ }^{\circ} \mathrm{C}$ and $70-75 \%$ R. H. 


\section{Results and Discussion}

\section{Chemical constituents of mint and peppermint oils}

Qualitative and quantitative analysis of mint (M. virdis) and peppermint (M. piperita) essential oils showed that both oils were mainly characterized by high concentration of total terpene compounds (88.53 and 92.67\%) respectively, and low concentration of sesquiterpenes (11.48 and 7.34\%) respectively, although their individual levels varied, in particular the concentration of some components such as, menthon (1.999 and $25.145 \%$ ) respectively, in addition, the variation in the individuals inside either oils.

Tables 1, 2, 3, 4 and Figs 1, 2 also show that mint oil was mainly characterized by high concentration of carvone $(57.351 \%)$, while menthone and menthol represented the main components in peppermint oil since they formed 25.145 and $21.633 \%$ of oil content respectively.

\section{Repellency, mortality and oviposition deterrence}

Table 5 shows that mint oil at all concentrations used, strongly deterred T. urticae adult females. At the lower concentration of mint oil, a considerable percent of $T$. urticae was recorded on treated half. Mortality was extremely high at $2 \%$ conc. after $72 \mathrm{~h}$ and was slightly at $0.125 \%$ conc. Percent repellency gradually decreased with peppermint oil concentrations. Mortality was nil and the number of eggs laid by females T. urticae after $72 \mathrm{~h}$ of treatment varied according to concentrations of peppermint oil (Table 5). No eggs were laid in case of mint oil. Harwood et al. (1990) demonstrated that reduced growth in larvae of the noctuid Peridroma saucia was the result of feeding inhibition in larvae fed menthone and pulegone and moulting abnormalities in larvae receiving menthol, as well as completely inhibited pupation. The essential oil of $M$. piperita was active against adult of Tribolium castaneum (Hbst) and toxic also to the newly hatched larvae of Pectinophora gossypiella (Saund.) and Earias insulana (Boisd.) (Shaaya et al., 1991; Hewady et al., 1994). Similar result has been also reported, that the essential oil of M. piperita and some of its main constituents (menthone and menthol) exhibited powerful acaricidal activities against Tyrophagous longior by direct contact and by inhalation (Perrucci et al., 1996). Tables 1, 2 show that the hydrocarbon terpenes and hydrocarbon sesquiterpenes content in mint was higher than on peppermint oil.

Chavan (1984) and Siddiqui et al. (1988) demonstrated that the hydrocarbon fraction isolated from dried neem leaves and twigs possessed larvicidal activity against mosquitoes. Similar results were recorded on T. urticae by El-Gengaihi et al. (1999), showing that the leaves of Moghat contained some hydrocarbons, so these hydrocarbons may be responsible for the effect itself or its occurrence with other hydrocarbons may cause synergistic effect, and finally increased activity.

\section{Concentration effects on reproduction and mortality}

Reproduction of $T$. urticae was greatly affected by both oils treatment. Significant reduction in the total number of eggs laid during 10 days period were found for all 
Table 1

Hydrocarbon terpenes content in mint and peppermint essential oils

\begin{tabular}{clcclc}
\hline Peak No. & Mint oil & $\%$ & Peak No. & Peppermint oil & $\%$ \\
\hline 1 & $\alpha$-Thujene & 0.011 & 1 & Tricyclene & 0.047 \\
2 & $\alpha$-Pinene & 0.421 & 2 & $\alpha$-Pinene & 2.576 \\
3 & Camphene & 0.110 & 3 & Camphene & 0.078 \\
4 & Sabinene & 0.230 & 4 & Sabinene & 0.752 \\
5 & $\beta$-Pinene & 0.547 & 5 & $\beta$-Pinene & 2.185 \\
6 & Myrcene & 0.240 & 6 & Myrecene & 0.510 \\
8 & D-Limonene & 14.162 & 8 & D-Limonene & 3.538 \\
9 & cis-Ocimene & 0.028 & 10 & cis-Ocimene & 0.065 \\
10 & trans-Ocimene & 0.005 & 11 & trans-Ocimene & traces \\
11 & $\gamma$-Terpinene & 0.006 & 12 & $\gamma$-Terpinene & 0.035 \\
& Unknown & 0.080 & & Unknown & 0.905 \\
& Total & 15.840 & & Total & 10.746 \\
\hline
\end{tabular}

Table 2

Oxygenated terpenes content in mint and peppermint oils

\begin{tabular}{clrclr}
\hline Peak No. & \multicolumn{1}{c}{ Mint oil } & $\%$ & Peak No. & Peppermint oil & $\%$ \\
\hline 7 & 2-Octanol & 0.369 & 7 & 3-Octanol & 1.159 \\
12 & cis-p-menth-2-en-1-01 & 0.021 & 9 & Cineole & 0.123 \\
13 & trans-Linalool oxide & 0.014 & 13 & Cis-p-menth-2-en-1-01 & 0.055 \\
14 & $\alpha$-Pinene oxide & 0.074 & 14 & Cis-Linalool oxide & 0.008 \\
15 & Linalool & 0.076 & 15 & Fenchone & 0.044 \\
16 & Menthone & 1.997 & 16 & Linalool & 0.009 \\
17 & trans-Dihydro terpineol & 1.591 & 17 & Camphor & 0.122 \\
18 & Neomenthol & 0.575 & 18 & Menthone & 25.145 \\
19 & Dihydro carveol & 0.138 & 19 & Isomenthone & 8.379 \\
20 & new iso-Dihydro carveol & 0.036 & 20 & Newmenthol & 8.782 \\
21 & Carvone & 57.351 & 21 & Menthol & 21.633 \\
22 & Isomenthyl acetate & 0.641 & 22 & $\alpha$-Terpineol & 0.204 \\
23 & Terpinenyl acetate & 6.030 & 23 & Pulegone & 3.252 \\
24 & cis-Carvyl acetate & 0.877 & 24 & Pipritone & 3.213 \\
27 & cis-Jasmone & 0.192 & 25 & Bornyl acetate & 3.707 \\
29 & Ionone & 0.220 & 26 & Isomenthyl acetate & 0.373 \\
& Unknow & 2.481 & 27 & trans-Carvyl acetate & 0.056 \\
& Total & 72.683 & 29 & Eugenol & traces \\
& & & 30 & cis-Carvyl acetate & 0.114 \\
& & & 33 & Jasmone & 0.082 \\
& & & & Unknown & 5.514 \\
& & & & Total & 81.919 \\
\hline
\end{tabular}


Table 3

Hydrocarbon sesquiterpenes content in mint and peppermint oils

\begin{tabular}{clcclc}
\hline Peak No. & \multicolumn{1}{c}{ Mint oil } & $\%$ & Peak No. & Peppermint oil & $\%$ \\
\hline 25 & $\beta$-Bourbonene & 3.065 & 28 & D-Elmene & 0.190 \\
26 & $\beta$-Cubebene & 0.907 & 31 & Copaene & 0.088 \\
28 & $\beta$-Caryophyllene & 2.704 & 32 & $\beta$-Bourbonene+ $\beta$-cubebene & 1.129 \\
30 & $\beta$-Gurjunene & 0.253 & 34 & $\beta$-Caryophyllene & 2.068 \\
31 & Aromadendrene & 0.545 & 35 & $\alpha$-trans-Bergamotene & 0.159 \\
32 & $\beta$-Farnesene & 0.147 & 36 & Aromadendrene & 0.033 \\
33 & $\gamma$-Muurolene & 0.199 & 37 & $\beta$-Farnasene & 0.156 \\
34 & D-Germacrene & 0.163 & 38 & Germecrene D & 1.050 \\
35 & $\alpha$-Muurolene & 0.125 & 39 & $\alpha$-Longipinene & 0.081 \\
36 & $\alpha$-Farnesene & 0.012 & 40 & $\beta$-Bisabolene & traces \\
37 & $\gamma$-Cadinene & 0.112 & 41 & $\gamma$-Cadinene & 0.332 \\
38 & 15-cis-Calamenene & 0.076 & & Unknown & 0.518 \\
& Unknown & 1.444 & & Total & 5.824 \\
& Total & 9.752 & & & \\
\hline
\end{tabular}

Table 4

Oxygenated sesquiterpenes content in mint and peppermint oils

\begin{tabular}{clcclc}
\hline Peak No. & \multicolumn{1}{c}{ Mint oil } & $\%$ & Peak No. & Peppermint oil & $\%$ \\
\hline 39 & Caryophyllene oxide & 1.160 & 42 & Nerolidol & 0.047 \\
40 & $\tau$-Cadinol & 0.025 & 43 & Spathulenol & 0.013 \\
41 & $\alpha$-Cadinol & 0.033 & 44 & Caryophyllene oxide & 0.384 \\
& Unknown & 0.507 & 45 & $\tau$-Cadinol & 0.066 \\
& Total & 1.725 & 46 & $\alpha$-Cadinol & 0.058 \\
& & & 47 & $\alpha$-Bisabolol & 0.019 \\
& & & Unknown & 0.934 \\
& & & Total & 1.521 \\
\hline
\end{tabular}

the concentrations tested (Table 6). The depression in total number of eggs with high concentrations could be attributed to feeding inhibition and irritant effects of the formulation, causing depression on reproduction activity. Similar results have been reported by Gulati and Mathur (1995) indicating that mentha leaf powder was effective in bring about a decrease in the fecundity of Tyrophagous putrescentiae (Schrank) and reducing the mean egg numbers to $25.49 /$ female as compared to $98.16 \mathrm{egg} / \mathrm{female}$ in the control. Mortality percentage reached $100 \%$ with mint oil, however, with low concentration, the effect was pronounced with mint oil than peppermint oil. Mansour et al. (1986) reported that the most effective oil on Tetranychus cinnabarinus (Boisd) was M. piperita. In contrast the oil was not effective on Acanthoscelides obtectus Say a pest of bean Phaseolus vulgaris (L.) (Regnault-Roger and Hamraoui, 1993). The same authors in (1995) 


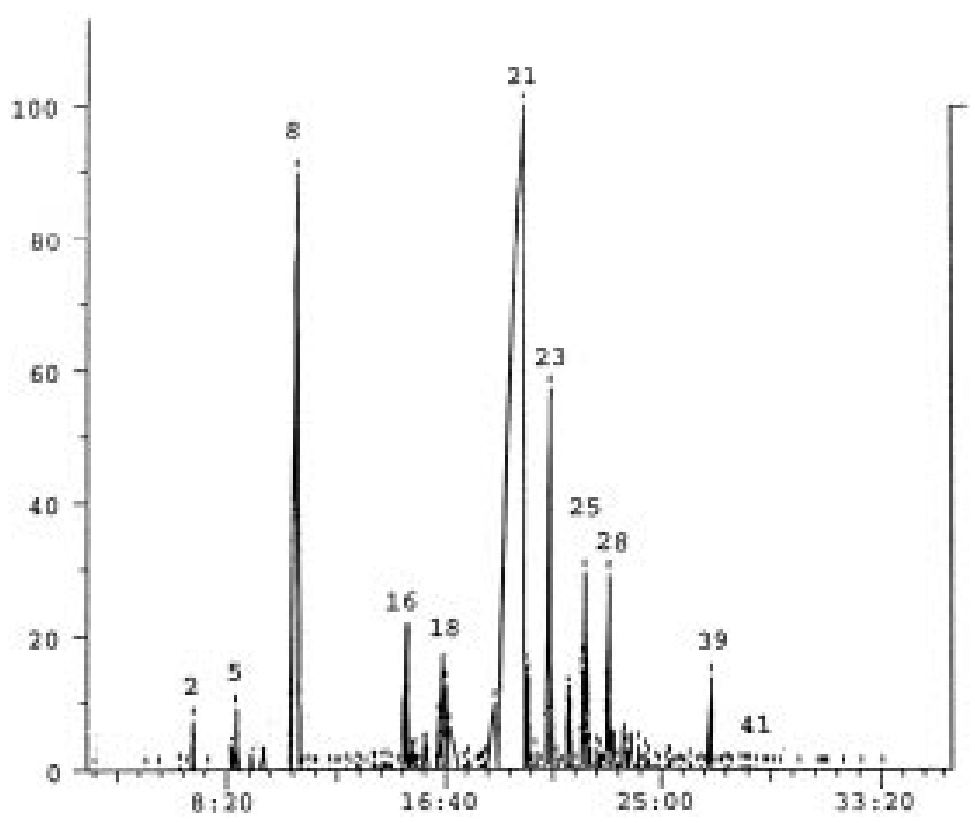

Fig. 1. Chromatogram of mint essential oil

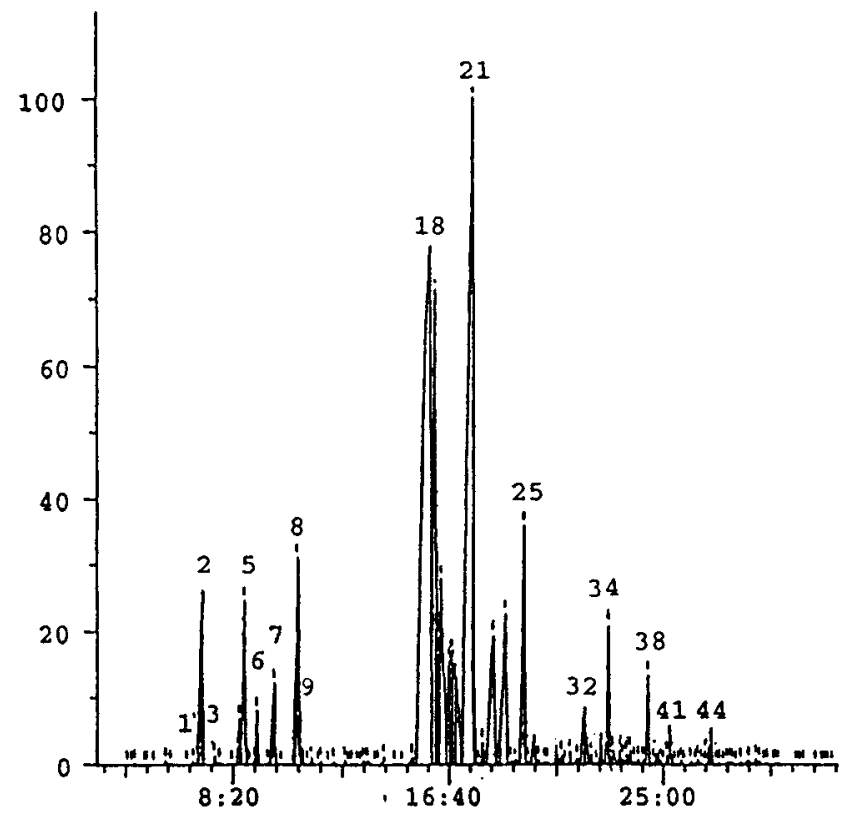

Fig. 2. Chromatogram of peppermint essential oil 
suggested that lipid as well as nonlipid allelochemical, such as phenolics, or nonprotein amino acids or flavonoids, may be involved in the toxicity of hydrodistillated and intact plant extracts from M. piperita to A. obtectus.

\section{Table 5}

Phagodeterrent activity of mint and peppermint oils against females of $T$. urticae

\begin{tabular}{|c|c|c|c|c|c|c|c|}
\hline \multirow[t]{3}{*}{$\begin{array}{c}\% \\
\text { Concentrations }\end{array}$} & \multicolumn{3}{|c|}{$\begin{array}{l}\% \text { Distribution of } \\
\text { mites on treated } \\
\text { leaf part after }\end{array}$} & \multirow{3}{*}{$\begin{array}{c}\% \\
\text { Mortality } \\
\text { after } \\
72 \mathrm{~h}\end{array}$} & \multirow{2}{*}{\multicolumn{2}{|c|}{$\begin{array}{c}\begin{array}{c}\text { Avg. No. of } \\
\text { eggs/female } \\
\text { after }\end{array} \\
72 \mathrm{~h}\end{array}$}} & \multirow[t]{3}{*}{$\begin{array}{c}\% \\
\text { Repellency }\end{array}$} \\
\hline & $24 \mathrm{~h}$ & $48 \mathrm{~h}$ & $\overline{72 h}$ & & & & \\
\hline & & & & & $\mathrm{T}$ & $\mathrm{C}$ & \\
\hline & & & & Mint oil & & & \\
\hline 2 & 0 & 0 & 0 & 75 & 0 & 0.05 & 100 \\
\hline 1 & 0 & 0 & 0 & 40 & 0 & 0.15 & 100 \\
\hline 0.5 & 0 & 0 & 5 & 20 & 0 & 0.65 & 100 \\
\hline 0.25 & 0 & 0 & 15 & 15 & 0 & 0.7 & 100 \\
\hline \multirow[t]{2}{*}{0.125} & 0 & 10 & 20 & 10 & 0 & 1.55 & 100 \\
\hline & & & & Peppermint oil & & & \\
\hline 2 & 15 & 15 & 20 & 0 & 0.05 & 0.5 & 90 \\
\hline 1 & 20 & 20 & 20 & 0 & 0.2 & 1.4 & 85.7 \\
\hline 0.5 & 25 & 30 & 35 & 0 & 0.3 & 1.4 & 78.6 \\
\hline 0.25 & 35 & 45 & 50 & 0 & 0.85 & 1.95 & 56.4 \\
\hline 0.125 & 45 & 55 & 55 & 0 & 1.05 & 1.95 & 46.2 \\
\hline
\end{tabular}

Table 6

Effect of mint and peppermint oils on reproduction and mortality of T. urticae

\begin{tabular}{|c|c|c|c|c|c|c|}
\hline \multirow{2}{*}{$\begin{array}{c}\% \\
\text { Concentrations }\end{array}$} & \multicolumn{3}{|c|}{ Mint oil } & \multicolumn{3}{|c|}{ Peppermint oil } \\
\hline & $\begin{array}{c}\text { Total no. of } \\
\text { eggs/female/10 days } \\
\pm \text { S. E. }\end{array}$ & $\begin{array}{c}\% \\
\text { ODI }\end{array}$ & $\begin{array}{c}\% \\
\text { Mortality after } \\
10 \text { days }\end{array}$ & $\begin{array}{c}\text { Total no. of } \\
\text { eggs/female/10 days } \\
\pm \text { S. E. }\end{array}$ & $\begin{array}{c}\% \\
\text { ODI }\end{array}$ & $\begin{array}{c}\% \\
\text { Mortality after } \\
10 \text { days }\end{array}$ \\
\hline 2 & $0 \pm 0$ & 100 & 100 & $0 \pm 0$ & 100 & 58.33 \\
\hline 1 & $0.55 \pm 0.11$ & 98.14 & 80 & $0 \pm 0$ & 100 & 21.43 \\
\hline 0.5 & $5.7 \pm 0.33$ & 82.24 & 66.67 & $3.90 \pm 0.22$ & 87.5 & 18.18 \\
\hline 0.25 & $6.2 \pm 0.33$ & 80.83 & 46.67 & $7.65 \pm 0.25$ & 76.87 & 0.00 \\
\hline 0.125 & $8.75 \pm 0.25$ & 73.98 & 26.67 & $9.0 \pm 0.15$ & 73.33 & 0.00 \\
\hline Control & $58.5 \pm 0.45$ & - & - & $85.5 \pm 0.45$ & - & 0.00 \\
\hline
\end{tabular}

High signigicant $\leq 0.01 \%$

\section{Direct effect of mint and peppermint oils on adult females of some predacious mites}

The data obtained in Tables 7 and 8 show that adult females of A. yousefi was more sensitive $\left(\mathrm{LC}_{50}=2.954 \%\right)$ to mint oil, while females of $T$. athiase was less susceptible $\left(\mathrm{LC}_{50}=16.15 \%\right)$. Results indicated also that peppermint oil was more toxic to the predacious mites tested than mint oil except for females of A. zaheri. Sopp et al. (1990) 
Table 7

Toxicity of mint oil to females of some predacious phytoseiid mites

\begin{tabular}{|c|c|c|c|c|c|c|c|}
\hline \multirow[t]{2}{*}{ Species } & \multirow[t]{2}{*}{$\begin{array}{c}\% \\
\mathrm{LC}_{50}\end{array}$} & \multirow[t]{2}{*}{$\begin{array}{c}\% \\
\mathrm{LC}_{90}\end{array}$} & \multirow[t]{2}{*}{ Slope } & \multicolumn{2}{|c|}{$\begin{array}{c}\text { Toxicity index } \\
\text { at }\end{array}$} & \multicolumn{2}{|c|}{$\begin{array}{l}\text { No. of folds } \\
\text { compared with } \\
\text { T. athiasae at }\end{array}$} \\
\hline & & & & $\mathrm{LC}_{50}$ & $\mathrm{LC}_{90}$ & $\mathrm{LC}_{50}$ & $\mathrm{LC}_{90}$ \\
\hline A. yoseffi & 2.954 & 11.81 & 2.13 & 100 & 100 & 5.47 & 15.66 \\
\hline A. zaheri & 5.530 & 42.50 & 1.45 & 53.42 & 27.79 & 2.92 & 4.35 \\
\hline P. finitimes & 6.882 & 14.77 & 3.86 & 42.92 & 79.96 & 2.35 & 12.52 \\
\hline A. barkeri & 8.796 & 31.25 & 2.33 & 33.58 & 37.79 & 1.84 & 5.92 \\
\hline A. deleoni & 12.09 & 114.2 & 1.31 & 24.43 & 10.34 & 1.34 & 1.62 \\
\hline T. athiasae & 16.15 & 184.9 & 1.21 & 18.24 & 6.39 & 1.00 & 1.00 \\
\hline
\end{tabular}

Table 8

Toxicity of peppermint oil to females of some predacious phytoseiid mites

\begin{tabular}{|c|c|c|c|c|c|c|c|}
\hline \multirow[t]{2}{*}{ Species } & \multirow[t]{2}{*}{$\begin{array}{c}\% \\
\mathrm{LC}_{50}\end{array}$} & \multirow[t]{2}{*}{$\begin{array}{c}\% \\
\mathrm{LC}_{90}\end{array}$} & \multirow[t]{2}{*}{ Slope } & \multicolumn{2}{|c|}{$\begin{array}{l}\text { Toxicity index } \\
\text { at }\end{array}$} & \multicolumn{2}{|c|}{$\begin{array}{l}\text { No. of folds } \\
\text { compared with } \\
\text { A. zaheri at }\end{array}$} \\
\hline & & & & $\mathrm{LC}_{50}$ & $\mathrm{LC}_{90}$ & $\mathrm{LC}_{50}$ & $\mathrm{LC}_{90}$ \\
\hline T. athiasae & 1.90 & 65.72 & 0.83 & 100 & 8.23 & 13.3 & 11.22 \\
\hline A. yoseffi & 2.314 & 6.277 & 2.95 & 82.11 & 86.19 & 10.92 & 117.48 \\
\hline P. finitimes & 2.890 & 9.504 & 2.47 & 65.74 & 56.92 & 8.74 & 77.59 \\
\hline A. deleoni & 2.92 & 19.14 & 1.57 & 65.07 & 28.27 & 8.65 & 38.53 \\
\hline A. barkeri & 3.72 & 5.41 & 7.89 & 51.08 & 100 & 6.79 & 136.30 \\
\hline A. zaheri & 25.27 & 737.40 & 0.87 & 7.52 & 0.73 & 1.00 & 1.00 \\
\hline
\end{tabular}

reported that Phytoseiulus persimiles A. H. was relatively unaffected by the beta-acids showing only a small reduction in the number of eggs laid. Mansour et al. (1993) revealed that RD9-Repelin was highly toxic to T. athiasae but Margosan-O and Azatin were not toxic. Research carried out by Momen and Amer (1994) and Momen et al. (1997) demonstrated that Lupin and canna extracts were toxic to females A. barkeri, also Neem Azal-F appeared to be harmless for A. barkeri and A. zaheri. Pyrethrum and rotenone had a negative effect on Typhlodromus exhilaratus Ragusa, and also stinging nettle and bitter wood were not effective on the predator (Tsolakis et al., 1997).

\section{Conclusion}

On scrutinizing our results, it will be shown that $M$. virdis is satisfactory as regards both high mortality and low reduction of fecundity for T. urticae. M. virdis was more toxic to T. urticae than to phytoseiid predators studied. In contrast, M. piperita was 
more effective on most phytoseiid predators than $M$. virdis, as well as it was considered to be less toxic to T. urticae than M. virdis. However, M. virdis can protect agricultural crops by direct or delayed pesticidal effect, through increased adult mortality and inhibition of reproduction. In integrated control programmes, therefore a careful choice of essential oil should be made to harm phytoseiid populations as little as possible. Consequently, knowledge about possible adverse affects of specific essential oil is essential. Field and laboratory data on the toxicity of such compounds to predacious mites should be obtained.

\section{Literature}

Abbott, W. S. (1925): A method of computing the effectiveness of an insecticide. J. Econ. Entemol. 18, 265-267.

Abou-Elella, G. M. (1998): Studies on certain aspects of some predacious phytoseiid mites. Ph.D. Thesis, Cairo University, 183 pp.

Adams, R. A. (1989): Identification of essential oils by Ion Trap Mass Spectroscopy. Academic Press, Inc., New York.

Amer, S. A. A., Abou-Awad, B. A. and El-Banhawy, E. M. (1993): Toxicity of the orange peel and lemon grass oils to the spider mites Tetranychus urticae and Eutetranychus orientalis with effects on the development and reproduction (Acari: Tetranychiadae). Afr. J. Agric. Sci. 20, 95-102.

Chavan, S. R. (1984): Natural pesticides from the neem tree and other tropical plants. - Proceeding of 2nd International Neem Conference - Rauischholzhausen Fed. Rep. Ger., 25-28 May, 1983.

Deans, S. G. and Ritchie, G. (1987): Antibacterial properties of plant essential oils. Int. J. Food. Microb. 5, 165-180.

Don-Pedro, K. N. (1985): Toxicity of some citrus peels of Dermestes maculatus Deg. and Callosobruchus maculatus (F.). J. stord Prod. Res. 81, 31.

El-Banhawy, E. M. (1974): Life history studies on the predatory mite Phytoseius finitimus Ribaga (Acarina: Phytoseiidae). Rev. Brasil. Biol. 34, 437-442.

El-Gengaihi, S., Amer, S. A. A. and Mohamed, S. M. (1996): Biological activity of Thyme oil and Thymol against Tetranychus urticae Koch. Anz. Schad. Pflan., Umw. 69, 157-159.

El-Gengaihi, S., Ibrahim, N. A. and Amer, S. A. A. (1999): Chemical inverstigation of the lipoidal matter of Glossostemon bruguieri and the Acaricidal activity of its unsaponifiable fraction. Acarologia 40, 95-100.

Finney, D. J. (1952): Probit analysis a statistical treatment of the sigmoid response curve. Cambridge University Press.

Gulati, R. and Mathur, S. (1995): Effect of Eucalyptus and Mentha leaves and Curcuma rhizomes on Tyrophagaus putrescentiae (Schrank) (Acarina: Acaridae) in wheat. Exp. App. Acarology 19, 511-518.

Harwood, S. H., Moldenke, A. F. and Berry, R. E. (1990): Toxicity of peppermint monoterpenes to the variegated cutworm (Lepidoptera: Noctuidae). J. Econ. Entomol. 83, 1761-1767.

Hewady, M. A. A., El-Sherif, L. S. and Omar, A. M. (1994): Evaluation of four plant oils against newly hatched larvae of the cotton bollworm; Pectinophora gossypiella (Saund.) and Earias insulana (Boisd.) (Lepidoptera: Noctuidae). Ann. Agric. Sci. Moshtohor 32, 2097-2104.

Huffaker, C. G., van de Vrie, M. and McMurtry, J. A. (1970): Ecology of tetranychid mites and their natural enemies: a revieus II. Tetranychid populations and their possible control by predators: an evaluation. Hilgardia 40, 391-458.

Ibrahim, M. E., Abouzeid, A. H., Awad, N. E. and Amer, S. A. A. (1993): The essential oil and some extracts of Cotula cinerea L. and their biological activity on Tetranychus urticae. Egypt J. Applied Sci. 8, 1-14.

Kokkini, S. (1991): Chemical races within the genus Mentha L. In: Modern Methods of Plant Analysis, New Series 12, Linskens, H. F., Jackson, J. F. (eds). Springer, Berlin, pp. 61-75. 
Kokkini, S. (1992): Essential oils as taxonomics markers in Mentha. In: Advances in Labiateae Science; Harley, R. M., Reynolds, T. (eds). Royal Botanic Gardens: Kew, U. K. pp. 325-334.

Konstantopoulou, L., Vassilopoulou, L., Mavragani Tsipidou, P. and Scouras, Z. G. (1992): Insecticidal effects of essential oils. A study of the effect of essential oils extracted from eleven Greek aromatic plants on Drosophila auraria. Experientia 48, 616-619.

Lundgren, L. (1975): Natural plant chemicals acting as oviposition deterrents on cabbage butterflies Pieris brassicae (L.), Pieris rapae (L.) and Pieris rapi (L.). Zool. Sci. 4, 253-258.

Lwand, W., Hassanal, P. W., Niarge, M. F., Bentley, M. D., Delle Monache, F. and Jondiko, J. I. (1985): A new $6(\alpha$-hydroxy pterocarpon with insect antifeedent and antifungal properties from the roots of Tephrosia hildebrantii vatke. Insect Sci. Applic. 6, 537-547.

Mansour, F., Ascher, K. R. S. and Abo-Moch, F. (1993): Effects of Margosan-OTM, Azatin TM and RD9-Repelin on spider, and on predacious and phytophagous mites. Phytoparasitica 21, 205-211.

Mansour, F., Ravid, U. and Putievsky, E. (1986): Studies of the effects of essential oils isolated from 14 species of labiatae on the carmine spider mite, Tetranychus cinnabarinus. Phytoparasitica 14, 137-142.

Momen, F. M. (1995): Feeding, development and reproduction of Amblyseius barkeri (Acarina: Phytoseiidae) on various kinds of food substances. Acarologia 36, 101-105.

Momen, F. M. and Amer, S. A. A. (1994): Effect of some foliar extracts on the predatory mite Amblyseius barkeri (Acarina: Phytoseiidae). Acarologia 35, 223-228.

Momen, F. M. and El-Borolossy, M. (1999): Suitability of the citrus brown mite, Eutetranychus orientalis as prey from nine species of phytoseiid mites (Acari, Tetranychidae, Phytoseiidae). Acarologia 40 (in press).

Momen, F. M., Reda, A. S. and Amer, S. A. A. (1997): Effect of Neem-Azal-F on Tetranychus urticae and three predacious mites of the family phytoseiidae. Acta Phytopathologica et Entomologica Hungarica 32, 355-362.

Perrucci, S. (1995): Acaricidal activity of some essential oils and their constituents against Tyreophagous longior, a mite of stored food. J. Food. Protect. 58, 560-563.

Perrucci, S., Cioni, P. L., Flamini, G., Morelli, I. and Macchioni, G. (1996): Biological activity of some essential oils and their constituents against mite (Tyreophagous longior). Pests of Stored Foods. Atti convegno internazionale: Coltivazione e miglioramento di piante officinali, Trento, Italy, 2/3, 579-584.

Regnault-Roger, C. and Hamraoui, A. (1993): Influence of aromatic essential oils on Acanthoscelides obtectus Say, pest of beans (Phaseolus vulgaris L.). Acta-Botanica-Gallica 140, 217-222.

Regnault-Roger, C. and Hamraoui, A. (1995): Comparison of the insecticidal effects of water extracted and intact aromatic plants on Acanthoscelides obtectus, a bruchid beetle pest of kidney beans. Chemoecology 5/6, 1-5.

Shaaya-E., Ravid, U., Paster, V., Juven, B., Zisman, U. and Pissarev, V. (1991): Fumigant toxicity of essential oils against four major stored product insects. J. Chemical Ecology 17, 499-504.

Siddiqui, S., Mahmood, T., Siddiqui, B. S. and Faizi, S. (1988): Non terpenoidal constituents from Azadirachta indica. Plant Medica 89, 546.

Sopp, P. I., Palmer, A. and Pickett, J. A. (1990): The effect of a plant-derived anti-feedent on Tetranychus urticae and Phytoseiulus persimilis: "A first look". SROP/WPRS XIII/5, 198-201.

Su, H. C. F., Spenrs, R. D. and Mahany, P. G. (1972): Toxicity of citrus oils to several stored-product insectlaboratory evaluations. J. Econ. Ent. 65, 1438.

Swirski, E., Amitai, S. and Dorzia, N. (1967): Laboratory studies on the feeding development and oviposition of the predacious mite Typhlodromus athiasae P. and S. (Acarina: Phytoseiidae) on various kinds of food substances. Isr. J. Agric. Res. 17, 213-218.

Tare, V. and Sharma, R. N. (1988): Antifeedant action of some oils and their constituents on some agricultures pests. Proc. Nat. Symp. on Integr. Pest Control Progress and Prospective. (eds): Mohandas and G-koshy, Trivandrum. pp. 450-452.

Tsolakis, H., Leto, G. and Ragusa, S. (1997): Effects of some plant materials on Tetranychus urticae Koch (Acariformes, Tetranychidae) and Typhlodromus exhilaratus Ragusa (Parasitiformes, Phytoseiidae). ANPP-Fourth International Conference on Pests in Agriculture, Montpellier 6-8 January, pp. 239-245. 